\title{
アーク加熱風洞における高エンタルピ気流の静圧計測技術*1 Static Pressure Measurement of High Enthalpy Flow in Arc-Heated Wind Tunnel
}

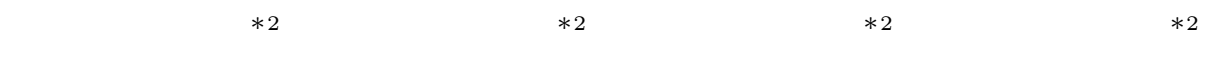 \\ Takashi MatsuZaki, Kiyomichi Ishida, Takeshi Ito, Takuji Kurotaki \\ 渡 辺泰 *2 $^{* 2}$ 福 井利 夫*3 \\ Yasuo Watanabe and Toshio FukuI
}

Key Words : Arc-Heated Wind Tunnel, Uniform Flow Evaluation, High Enthalpy Flow

\begin{abstract}
NAL has been promoting diagnostic study of the $750 \mathrm{~kW}$ arc-heated wind tunnel flow to characterize various important flow parameters, such as heat flux and pressure, necessary for determining materials test conditions. In those measurement techniques, static pressure data is one of the most difficult experimental items to obtain. In this report, design of a static pressure probe and measurement system for the pressure, calibration system and the results, and evaluation of response time of the pressure are presented. The results show that static pressure distributions of the high enthalpy air flow in the NAL/NASDA $750 \mathrm{~kW}$ arc-heated wind tunnel were obtained with good accuracy using these techniques.
\end{abstract}

\section{1. は じめに}

宇宙往還機の熱防護材料の開発評価試験は，一般にアー ク加熱風洞等で作り出される高エンタルピ気流中で行われ る. 航空宇宙技術研究所と宇宙開発事業団では, これまで $750 \mathrm{~kW}$ アーク加熱風洞を用いて各種熱防護材料試験を実 施してきた . 本アーク加熱風洞は, 作動気体をマルチセグ メント式縮流型アーク加熱器で加熱し, スロート径 $25 \mathrm{~mm}$, 出口径 $115 \mathrm{~mm}$, 半頂角 15 度のコニカルノズルで加速膨張 して極超音速の高エンタルピ気流を得るものである . アー ク加熱器パック数 (アーク長) や電流值および作動気体流 量の制御により気流条件を設定し, 最大気流エンタルピ約 $20 \mathrm{MJ} / \mathrm{kg}$ を得ることができる ${ }^{1,2)}$.このアーク加熱風洞で 実施される試験では，加熱率およびピト一圧の計測により 気流条件を決定してきたが，CFD との比較や表面触媒性 の評価のために更に詳細な気流の診断が必要とされている . 具体的には, 気流のマッハ数や温度を推定するため, これ まで計測されているピト一圧に加え, 気流の静圧を計測す ることが必要な項目の一つである . ところが , 静圧計測に は, 流れを乱さない細長い形状でありながら超高温気流中 に投入を可能とする静圧管の開発や，長い配管を用いなが ら低い圧力を計測する技術など，各種の困難が伴う. 本報 告では, これらの問題を解決するため, 新たに設計した静 圧プローブと圧力計測システムおよび必要となる較正シス

\footnotetext{
*1 (C) 2002 日本航空宇宙学会

平成 9 年 10 月 22 日, 第 41 回宇宙科学技術連合講演会にて講 演. 平成 14 年 3 月 5 日原稿受理

*2 航空宇宙技術研究所

$* 3$ 宇宙開発事業団
}

テムなどについて述べ，これを用いた風洞気流の静圧計測 結果を報告する．

\section{2. 静 圧 管}

静圧管は気流を乱さないように先端を尖らせると同時に， 可能な限り管の外径を小さくすることか望ましい．今回設 計した静圧管 (第 1 図) では, 高エンタルピ流中で溶融し ないように, 先端の円錐部の半頂角は $6.8^{\circ}$ とし, 内部を冷 却水で強制冷却するため, 外径は $\phi 12 \mathrm{~mm}$ とした . 材料 は熱伝導の良い銅を使用した . 静圧孔の直径は $\phi 1 \mathrm{~mm}$ で， 静圧管の周方向に $90^{\circ}$ 間隔で 4 個あり, 各圧力孔が 1 本の 圧力配管につながっている．理想気体において超音速流用 静圧管に沿う圧力は, 管直径の約 10 倍程度で流れ場の静 圧にほぼ等しくなるとされているが3), 本静圧管は, 風洞 のノズル出口から拡散筒の間のスペース (約 $220 \mathrm{~mm}$ ) の制 約を受け, 先端から静圧孔までの距離は $100 \mathrm{~mm}$, 光の外径 に対する比は 8.3 となった . 上述した理想気体条件での静 圧孔位置までの圧力回復は約 $97 \%$ 程度であり ${ }^{3)}$, 約 $3 \%$ 程度 の誤差が見込まれる .

\section{3. 静圧計測システムと圧力較正}

本静圧計測システムに使用する圧力センサーは , 隔膜静電 容量型の絶対圧型センサーで, 計測圧力範囲は $0 \sim 266.6 \mathrm{~Pa}$, 精度は読みとり值の $0.25 \%$, 分解能は $0.0266 \mathrm{~Pa}$ である . ま た，別途これを較正するための標準圧力計があり，圧力範 囲は $0 \sim 13.3 \mathrm{kPa}$, 精度は読みとり值の $0.08 \%$, 分解能は $0.0133 \mathrm{~Pa}$ であり，0〜133 Pa の範囲で米国 NIST の圧力基 準器に対し $0.05 \%$ 未満の誤差でトレーサビリティを持つ. 


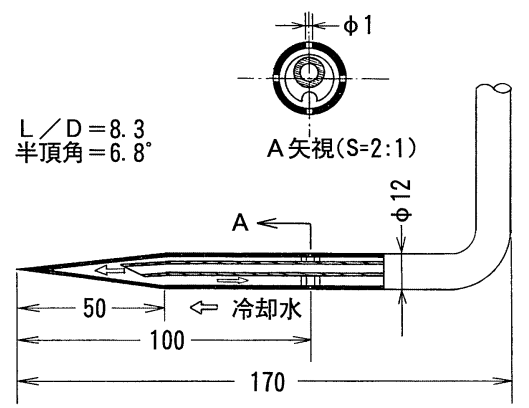

第 1 図 静圧管概要図

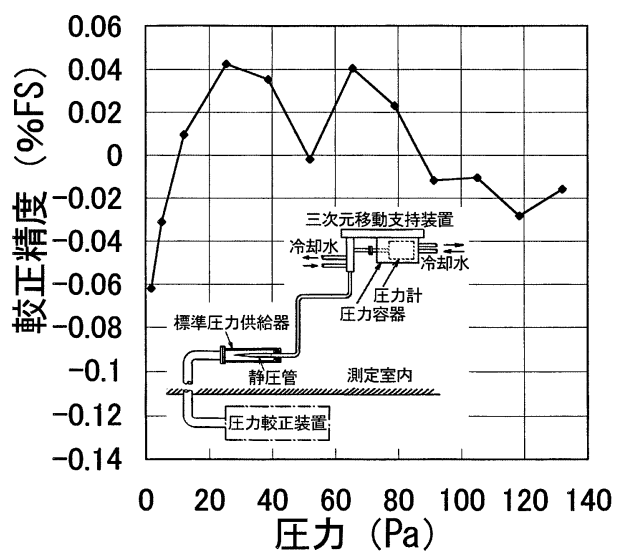

第 2 図 静圧管の圧力較正の精度

以下の較正はこの標準圧力計を用いて行った .

第 2 図中に示されているように, 今回の圧力較正システ ムでは, 風洞試験時に用いる静圧管に標準圧力供給器を取 り付けて圧力を供給することにより，圧力センサーだけで なく静圧管およひ計測用配管 (内径 $\phi 2 \mathrm{~mm}$, 長さ $890 \mathrm{~mm}$ ) を含む圧力計測系全体を較正する .このシステムにより圧 力計測系の配管や継ぎ手等からのわずかなアウトガス等を 含めた較正が可能となり，圧力計測システム全体の精度を 高めることができる. 本較正により得られた較正直線を適 用した静圧計測データと標準圧力供給器の圧力との誤差を 第 2 図に示す . 低圧時には圧力のばらつきが大きく, 配管 からのアウトガスなどが存在する可能性があるが, 静圧計 測系の精度として $0.06 \% \mathrm{FS}$ 以下との結果が得られ, 計測 システムとして十分な精度があることか確認できた .なお， アウトガスは配管の加熱や計測時間を長くとることて軽減 可能ではあるが，実験実施上の時間の制約等から現実的で はない .

\section{4. 圧力応答特性}

風洞気流の圧力測定では, 圧力配管が長くなるにつれて 管の抵抗係数が増大し, 圧カレベルの低い静圧計測等では 圧力応答時間が非常に長くなる .このため, 圧力センサー を測定室内に設置して配管をできるだけ短くした .この際， 測定室の低圧高温環境から圧力センサーを保護するために， 圧力容器にセンサーを設置し, 冷却水で冷却するとともに

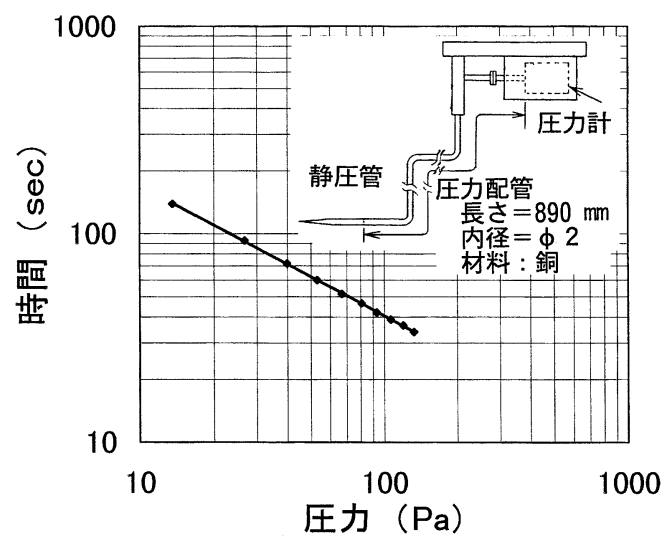

第 3 図 静圧計測システムの圧力応答時間

第 1 表 試験条件

\begin{tabular}{lccc}
\hline & Case 1 & Case 2 & Case 3 \\
\hline ガス流量 $(\mathrm{g} / \mathrm{sec})$ & 16.0 & 12.0 & 8.0 \\
アーク電流 $(\mathrm{A})$ & 600 & 500 & 400 \\
加熱器入力電力 $(\mathrm{kW})$ & 609 & 440 & 287 \\
加熱器内圧力 $(\mathrm{kPa})$ & 86.6 & 66.1 & 45.6 \\
エンタルピ $(\mathrm{MJ} / \mathrm{kg})$ & 19.2 & 18.4 & 17.8 \\
\hline
\end{tabular}

大気圧に保持して計測を行うこととした．

この状態で, アーク加熱風洞の気流持続時間 (約 20 分) 内に十分な圧力応答があるかどうかを確認する必要がある。 このため, 圧力応答試験装置 ${ }^{4)}$ を使用し, 真空状態から瞬 間的に一定圧力が加わる本風洞の圧力計測の状態を模擬し て圧力応答を調べた . 本試験装置は圧力孔をオリフィス (直 径 $\phi 1 \mathrm{~mm})$ て模擬し, 静圧測定用の配管直径 $(\phi 2 \mathrm{~mm})$ お よび長さ $(890 \mathrm{~mm})$ の同じ配管を用いて圧力応答を実験的 に求めるものである . 得られた静圧計測システムの圧力応 答時間として , 設定圧力の $98 \%$ までの到達時間を第 3 図に 示す . 圧力応答時間は, 静圧の測定圧力範囲 $(13 \sim 133 \mathrm{~Pa})$ に対し，約 130 32 secであった . 本静圧測定系の応答時間 は, アーク風洞通風時間に比べ十分短く, 計測が可能であ ることが確認された .

\section{5. アーク風洞気流中の静圧分布計測}

アーク加熱器はアーク長が最大となる形態で , このとき アーク長は約 $590 \mathrm{~mm}$, 作動ガスは空気を用い, 第 1 表の気 流条件において，三次元移動支持装置に取り付けた静圧管 によりノズル出口下流 $40 \mathrm{~mm}$ から $140 \mathrm{~mm}$ までの範囲で 計測を行った . 試験中の写真を第 4 図に示す . 先端の尖っ た静圧管が, 高エンタルピ気流によって強く加熱されてい るが，管の強制冷却により計測に問題となる溶融等は生じ ていない，また，計測にあたっては，先に行った圧力配管 計測系の応答時間をふまえ，十分に時間が経過し，圧力値 が定常になったと判断できる状態のデータを取得した .

3 種類の気流条件に対し, ノズル出口の下流 $40 \mathrm{~mm}$ から $140 \mathrm{~mm}$ まで $20 \mathrm{~mm}$ 間隔で取得した気流中心軸上の静圧分 布を第 5 図に示す . 得られた静圧の範囲は 10 112 Paであ り，圧力較正により精度の良いデータ取得が可能な範囲内 


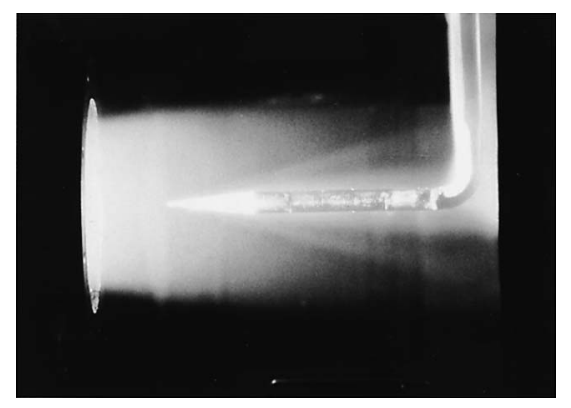

第 4 図 アーク加熱風洞気流中の静圧管

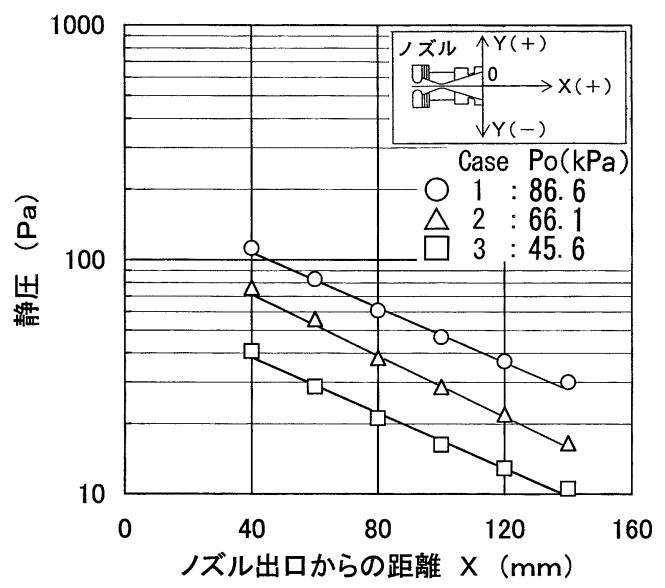

第 5 図 静圧計測結果

におさまっている . 得られた結果は , ノズルからの距離に 比例して静圧は光れ光れ指数関数的に減少し, 超音速膨張 流であることを示しており，定性的には妥当な結果である．

また，熱防護材料の表面触媒性評価のための加熱率解析 では，当初，気流条件の確認にピト一圧データのみを用い ていたため気流マッハ数に誤差が存在し, CFD 解析結果か ら得られた加熱率が, 試験と大きく異なる值を示した。し かし，本報告で確立された技術を用いた静圧計測によって， 供試体試験位置でのマッ八数を得ることが可能となり，こ れを CFD 解析にフィードバックすることで，実験と良く 一致した結果を得ることができた ${ }^{5)}$. 具体的には，本計測 結果の適用前には, 空力加熱率についての風洞試験結果と CFD 解析值との間に解析モデルの誤差では説明できない 大きな差が存在していたものが, 静圧計測值を CFD 解析
にフィードバックすることで , 約 10\%の誤差内に収めるこ とができた .これらの成果から，本静圧計測の妥当性か確 認できたと考えられる．今後は，本静圧管の太さをより細 くする最適設計を行うことにより，気流への影響を更に小 さくして計測精度の信頼性を上げることか課題である．

$$
\text { 6. ま と め }
$$

高エンタルピ中の各種熱防護材料の試験において気流の 静圧を計測するため，流れを乱さず高エンタルピ気流中に 投入可能なプローブや，長い配管を用いて低い圧力を計測 するための計測およひ較正システム技術の開発を行った . 本 静圧計測システムに関し，

1) 高エンタルピ中の圧力計測では強制冷却の必要性から計 測プローブの径を大きくする必要があり，理想的な静圧 管設計は困難であるが , 圧力回復に関する誤差が $3 \%$ 程 度の静圧管を設計することができた．

2) 配管が細く，長いため, 圧力応答に時間がかる .この 応答時間の評価を行い, 本システムでは計測に必要な時 間は最大で約 2 分程度が必要であった .

3) 計測圧力が低いため, アウトガス等の影響を排除する必 要がある .このため, 圧力較正を測定システム全体につ いて行った結果, 誤差を $0.06 \% \mathrm{FS}$ 以下とすることがで きた 。

4) アーク加熱風洞において高エンタルピ気流の静圧計測を 行い, 妥当な結果を得た。

以上のように，アーク加熱風洞気流における静圧計測技 術を確立することができた .

$$
\text { 参 考 文 献 }
$$

1) Smith, R. K., Wagner, D. A., Cunningham, J., Painter, J. H., Itagaki, H., Watanabe, Y. and Hasegawa, S.: High Enthalpy Material Test Facility Design Improvements in Japan, AIAA Paper 94-2592, 1994.

2）松崎貴至, 石田清道, 渡辺泰夫, 三保和之, 板垣春昭, 芳仲敏 成 : $750 \mathrm{~kW}$ アーク加熱風洞の構造と動作特性, NAL TM-760, 2001.

3) Shapiro, A. H.: The Dynamics and Thermodynamics of Compressible Fluid Flow, Vol. 2, The Ronald Press, New York, 1954, p. 697.

4）松崎貴至 , 井上安敏 : 軌道再突入実験における高々度圧力計測, NAL TR-1281, 1995.

5) 黑滝卓司, 伊藤 健, 松崎貴至, 石田清道, 渡辺泰夫 : アーク加 熱風洞試験における熱防護材表面触媒性の CFD 評価について， 第 33 回流体力学講演会講演集, 2001, pp. 73-76. 